\title{
Supplementary Information: Protocols
}

\section{Expression of alternative nitrogenases in Rhodopseudomonas palustris is enhanced using an optimised genetic toolset for rapid, markerless modifications}

Jan-Pierre du Toit ${ }^{1}$, David J. Lea-Smith ${ }^{2,3}$, Anna Git ${ }^{3}$, John R. D. Hervey ${ }^{3}$, Christopher J. Howe ${ }^{3}$, Robert W. M. Pott ${ }^{1,{ }^{*}}$

${ }^{1}$ Department of Process Engineering, Stellenbosch University, Banghoek road, Stellenbosch, 7600, South Africa

${ }^{2}$ School of Biological Sciences, University of East Anglia, Norwich Research Park, Norwich, NR4 7TJ, United Kingdom

${ }^{3}$ Department of Biochemistry, University of Cambridge, Hopkins Building, Downing Site, Tennis Court Road, Cambridge, CB2 1QW, United Kingdom.

*Corresponding author: rpott@sun.ac.za

\section{Supplementary Protocol 1: R. palustris electrocompetent cell preparation}

\section{Materials: all sterile}

- Van Niel's Yeast medium with $50 \mathrm{mM}$ glycerol (VNG medium): $1 \mathrm{~g} \mathrm{~K}_{2} \mathrm{HPO}_{4}, 0.5 \mathrm{~g} \mathrm{MgSO}_{4}, 10 \mathrm{~g}$ yeast extract per litre (final $\mathrm{pH} \sim 7.1$ ).

Add $10 \mathrm{~mL}$ sterile $5 \mathrm{M}$ glycerol solution aseptically after autoclaving.

- $10 \%$ glycerol solution, sterile-filtered $(0.2 \mu \mathrm{m})$

- $50 \mathrm{~mL}$ centrifuge tubes

\section{Electrocompetent cell preparation:}

1. Inoculate $50 \mathrm{~mL}$ VNG medium in $50 \mathrm{~mL}$ tubes. Grow in light with shaking $\left(35^{\circ} \mathrm{C}\right) \sim 2$ days until $\mathrm{OD}_{660}=0.3$ $-0.6(\max 1.0)$

Fast growth in VNG results in high cell viability; freshly-grown nonstationary-phase cells are important for high transformation efficiency.

2. Chill tubes and $10 \%$ glycerol on ice $\sim 15 \mathrm{~min}$

3. Centrifuge $\sim 4000 \times g$ at $4^{\circ} \mathrm{C} ; 10$ mins.

Higher force makes pellet difficult to resuspend.

4. Resuspend / wash cell pellet $3 \mathrm{X}$ with $50 \mathrm{~mL}$ aliquots of ice-cold $10 \%$ glycerol; centrifuging as before for $10 \mathrm{~min}$.

Pellets are easier to resuspend in small volume by vortexing, before topping up to $50 \mathrm{ml}$.

5. Resuspend pellet in $0.5-1 \mathrm{~mL} 10 \%$ glycerol

(or just enough for homogeneous suspension with no clumps)

6. $100 \mu \mathrm{L}$ aliquots can be quick-frozen on dry ice and stored at $-80^{\circ} \mathrm{C}$

\section{Notes:}

- It is advisable to routinely streak cultures on VNG plates before preparing electrocompetent cells; contamination generally shows up overnight at $35^{\circ} \mathrm{C}$ 


\section{Supplementary protocol 2: R. palustris electro-transformation procedure}

\section{Materials: all sterile}

- Purified plasmid in water (high concentration preferable, with low or no salt present)

- Microfuge tubes

- $2 \mathrm{~mL}$ screw-cap tubes

- $1 \mathrm{~mm}$ gap electroporation cuvettes (eg. VWR brand)

- Electroporator e.g. BioRad GenePulser

- Electrocompetent cells (from above)

- VNG agar plates with $200-400 \mu \mathrm{g} / \mathrm{mL}$ kanamycin (or antibiotic suitable for plasmid)

\section{Electroporation procedure:}

1. Chill electroporation cuvettes and VNG medium on ice

2. Add $\sim 500 \mathrm{ng}$ plasmid to $1.5 \mathrm{~mL}$ tube on ice (for VWR brand electroporation cuvettes with $100 \mu$ l capacity)

3. Add $100 \mu \mathrm{L}$ electrocompetent cells, mix gently by pipetting

4. Pipette into chilled cuvette, tap to remove any bubbles

5. Electroporate: $2.0 \mathrm{kV}, 800 \Omega, 25 \mu \mathrm{F}$ pulse (time constant $<17 \mathrm{mSec}$ is good) - chill on ice immediately and keep cold throughout

Depending on construct, $600 \Omega$ may result in higher transformation efficiency

6. Promptly add $900 \mu \mathrm{L}$ ice-cold VNG medium. Transfer to $2 \mathrm{~mL}$ screw cap tube and use another $900 \mu \mathrm{L}$ to rinse out cuvette and add to tube

7. Keep on ice 5 min

8. Incubate overnight at $30^{\circ} \mathrm{C}$ in light with shaking ( 18 hours)

9. Plate $100-200 \mu \mathrm{L}$ volumes on VNG plates with antibiotic

10. Incubate at $30-35^{\circ} \mathrm{C}$ until colonies form ( $3-5$ days typically)

11. Patch colonies out onto fresh plates and screen by colony PCR

\section{Notes:}

- R. palustris shows high resistance to antibiotics in general so higher concentration may reduce rate of false positives.

- Marked, $1^{\text {st }}$ recombination strains with pK18mobSacB are unstable so second recombination step should be completed promptly after PCR screening. 


\section{Supplementary protocol 3: Optimised R. palustris RNA isolation procedure}

\section{Materials:}

- RNase-free microfuge tubes (from unopened package, not autoclaved)

- $2 \%$ SDS in RNase-free Tris-EDTA (TE) buffer, pH 8 (Invitrogen)

- Tri reagent (Sigma), TriZol (Thermofisher) or equivalent [HAZARDOUS]

- Zymo Research Direct-zol RNA miniprep kit (Cat \# R2050)

- RNase-free $96 \%$ ethanol

User should be familiarised with requirements for avoidance of RNase contamination

\section{Procedure:}

Reagents in bold are supplied with the Direct-zol kit

1. Grow cultures under desired conditions to medium density - not opaque; $O D_{660}<2$

2. Centrifuge $1 \mathrm{~mL}$ of culture, $5 \mathrm{~min}$ at $14000 \times \mathrm{g}$

Smaller volume should be used if dense culture - not more than $2 O D \times m L$ to maintain high RNA integrity e.g. $O D 3=2 / 3 \mathrm{~mL}$

3. Pipette off supernatant

4. Resuspend cells in $55 \mu \mathrm{L} 2 \%$ SDS in RNase-free TE buffer, $\mathrm{pH} 8$ (Invitrogen) in $1.5 \mathrm{~mL}$ tube

5. Incubate at $65^{\circ} \mathrm{C}$ for $20 \mathrm{~min}$

Preferably in thermomixer; 30s mix, 1:30 off

6. Add $640 \mu \mathrm{L}$ Tri reagent, mix by pipetting until homogeneous

7. Leave on carousel mixer for $\sim 15$ min at room temp. (RT)

8. Stopping point: store at $-20^{\circ} \mathrm{C}$

9. Centrifuge to pellet cell debris ( $5 \mathrm{~min}, 14000 \times \mathrm{g})$

10. Pipette off supernatant and add to equal volume $96 \%$ ethanol $-700 \mu \mathrm{L}$

11. Apply to Zymo Direct-Zol column in 2 aliquots of $700 \mu \mathrm{L}$ (30s spins, as per supplied protocol)

12. Wash with $400 \mu \mathrm{L}$ RNA wash buffer

13. Transfer column to new collection tube

14. Mix $5 \mu \mathrm{L}$ DNase I + $75 \mu \mathrm{L}$ DNA digestion buffer in RNase free tube, apply to column matrix

15. Incubate at least $20 \mathrm{~min}$ at RT ( 30 mins preferable)

16. Centrifuge $30 \mathrm{~s}$

17. Wash with $400 \mu \mathrm{L}$ RNA pre-wash

18. Discard flow-through \& repeat washing with pre-wash solution

19. Wash with $700 \mu \mathrm{L}$ RNA WASH buffer, centrifuge $1 \mathrm{~min}$.

20. Empty collection tube \& centrifuge another 2 min to fully dry column.

21. Transfer to RNase-free $1.5 \mathrm{~mL}$ tube

22. To elute add $50 \mu \mathrm{L}$ Nuclease free water directly to matrix, incubate $>1 \mathrm{~min}$. Centrifuge $1 \mathrm{~min}$.

23. Store at $-80^{\circ} \mathrm{C}$, keeping $5 \mu \mathrm{L}$ sample aside for nanodrop (concentration/purity) and gel electrophoresis or Agilent BioAnalyzer to determine RNA integrity. 